\title{
Earnings Yield as a Predictor of Return on Assets, Return on Equity, Economic Value Added and the Equity Multiplier
}

\author{
Rebecca Abraham, Judith Harris, Joel Auerbach \\ Huizenga College of Business, Nova Southeastern University, Fort Lauderdale, Florida, USA \\ Email: abraham@nova.edu, harrisj@nova.edu, jauerbac@nova.edu
}

How to cite this paper: Abraham, R., Harris, J. and Auerbach, J. (2017) Earnings Yield as a Predictor of Return on Assets, Return on Equity, Economic Value Added and the Equity Multiplier. Modern Econo$m y, 8,10-24$.

http://dx.doi.org/10.4236/me.2017.81002

Received: December 5, 2016

Accepted: January 6, 2017

Published: January 9, 2017

Copyright ( $\odot 2017$ by authors and Scientific Research Publishing Inc. This work is licensed under the Creative Commons Attribution International License (CC BY 4.0).

http://creativecommons.org/licenses/by/4.0/

\begin{abstract}
This study identifies earnings yield as a measure of financial performance that is based on a firm's ability to sell profitable goods. It excludes the irrationality that can confound market-based measures of financial performance by emphasizing a firm's ability to earn profits as the indicator of superior performance. For the full sample, the differential effects of earnings yield on return on assets, return on equity, stock returns, economic value added and the equity multiplier are determined for firms of different size and volatility. The analysis is conducted both across industries and within the oil and gas, computer software, biotechnology and retail industries. For the full sample of NASDAQ stocks from 2010-2014, earnings yield significantly explained return on assets, return on equity, stock returns, economic value added and the equity multiplier beyond book value and book to market. The influence of earnings yield on return on assets was predictable with linear relationships and autocorrelated residuals, while that for small firms was unpredictable with nonlinear relationships between earnings yield and all outcomes with heteroscedastic residuals. In the oil and gas industry, small producers with low market risk and high firm-specific risk, i.e. drillers in new locations with existing technology, found that earnings yield was related to all outcome measures, while large, high-market risk firms, or drillers using the new shale rock techniques strove for operational efficiency through higher return on assets and return on equity. Market risk demarcates small biotechnology firms with those with low market risk demonstrating the explanation of return on assets by earnings yield, while earnings yield is significantly related to economic value added for high market risk firms. In large biotechnology firms, earnings yield was significantly related to all outcomes. Similar results were obtained for the computer software industry. Retail is in retrenchment with small retailers selling traditional product lines emphasizing return on assets or being operationally efficient for survival, while large retailers borrow against large-
\end{abstract}


scale investments in assets, as shown by the significant explanation of the equity multiplier by earnings yield. It may be concluded that earnings yield measures multiple dimensions of financial performance for firms of different size and volatility levels in multiple industries. For small firms, the ability of earnings yield to measure the productivity of capital through economic value added is noteworthy. For large firms, earnings yield is particularly effective in predicting operational efficiency or return on assets.

\section{Keywords}

Earnings Yield, Stock Returns, Economic Value Added, Equity Multiplier

\section{Introduction}

Earnings yield is defined as the ratio of net income to price, or the reciprocal of the price-earnings ratio. Intuitively, it is the portion of variation in the stock price that is attributable to changes in corporate profitability. It is the ability of firms to earn profits from the sale of goods and services, or the fundamental ability to succeed in employing resources to produce a stream of products that attract a growing customer base. Thus, it is a true measure of corporate performance based value-creation. Such a measure sets earnings yield apart from market-based measures which may be based on the day's news, unrealistic expectations, analyst hype and herd hysteria. From a business standpoint, earnings yield improves the accuracy of performance measurement over earnings which may be manipulated through earnings management. Managers may be evaluated on the basis of earnings, so that they may postpone necessary investments in training and upgrading equipment to show higher earnings. In contrast, earnings yield relates earnings to price so that any inflation of earnings will be reflected in reduction in stock prices and negative impact on return on assets or return on equity. From a practical standpoint, this study presents earnings yield as a rational measure of corporate performance which describes performance in the four crucial areas of operational efficiency (measured by return on assets), return to shareholders (measured by return on equity and stock returns), productivity of capital (economic value added) and debt capacity (equity multiplier). From academic standpoint, this study sets forth earnings yield as a measure of financial performance that explains both financial statement measures such as return on assets and equity multiplier and market measures including return on equity, stock returns and economic value added. Earnings yield merits consideration as a separate entity as earnings are more variable than dividends, so that it explains the variation in stock returns beyond that due to dividends [1]. The technology firms listed on the NASDAQ have been achieving high net income with 1) higher revenue from the production of innovative products, or 2) reduced expenses from reliance on human capital with limited fixed costs for plant and equipment. Therefore, this study examines earnings yield for a sample of 
NASDAQ firms. The technology firms are lodged in the biotechnology and computer software industries. To preserve a point of comparison, two non-technology industries, oil and gas and retail, were included.

Our research contributes to the literature in two ways. First, it updates the pre 2010 literature on earnings yield. The concept was first defined in seminal papers by [2] and [3]. A series of studies followed to investigate the impact of earnings yield on stock returns ([4] [5] [6]) finding that as theorized, earnings yield was associated with stock returns and contributed to its unexplained variance. Second, we explore the effects of earnings yield on return on assets, return on equity, stock returns, economic value added and the equity multiplier beyond firm size and volatility for four industries.

Earnings yield may be expected to vary with size and volatility. In successive studies, [3] and [7] observed higher stock returns for small, high earnings yield portfolios on the American Stock Exchange and Korean Stock Exchanges, respectively. This study investigates the reasons for this phenomenon. We posit that small market-oriented firms will have net income that grows at a greater rate than the stock price. In other words, earnings yield of small firms may show greater increases in return on equity and stock returns than that of large firms. Large firms may show positive earnings yield depending upon their position in the product life cycle. Mature cash-cow products in established markets may be profitable at present, suggesting that earnings yield will be related to operational efficiency measured by return on assets in large firms. Large firms may have substantial assets against which they can borrow, indicating that their profitability growth, as measured by earnings yield, may contribute to a stronger asset base or the ability to borrow against their assets as measured by the equity multiplier.

Volatility refers to uncertainty in future cash flows. Highly volatile firms will have unpredictable future cash flows, while firms with low volatility will have predictable cash flows. Net income is the source of cash flows, given that net income + depreciation $=$ cash flows. It follows that volatility in cash flows is volatility in net income. As earnings yield = net income/stock price, volatility in net income translates to volatility in earnings yield. Firms with volatile earnings yield will demonstrate market risk or firm-specific risk. Institutions with high market risk will have future revenues that are predictable from past revenues or autocorrelated residuals in the regression of return on assets or return on equity on earnings yield. Firms with high firm-specific risk will have unpredictable future revenues or heterscedastic residuals in the regression of stock returns or other outcomes on earnings yield. Heteroscedastic residuals suggest that the variation of error terms in the regression does not follow a normal distribution or is unpredictable. Given that earnings yield may have differential effects on outcomes for firms of large or small size, or high or low market volatility or high or low firm-specific volatility, this study conducts an exploration of the influence of size and volatility on earnings yield-outcome relationships. 


\section{Hypotheses Development}

\subsection{Earnings Yield and Return on Assets}

By definition, earnings yield is the ratio of net income to the stock price. Return on assets is the ratio of net income to total assets. Growth in earnings yield suggests that net income is increasing at a higher rate than the stock price, or due to factors that are not driven by market variables. Such factors may be intrinsic measures of operational efficiency represented by the ability to generate income from the firm's investment in assets. One of the measures of such operational efficiency is return on assets. We propose the following hypothesis:

$\mathrm{H} 1$ : Earnings yield is a significant predictor of return on assets.

\subsection{Earnings Yield and Return on Equity}

Intuitively, investors purchase stock in a firm with the expectation of earning dividends and capital gains from the appreciation in stock prices. Net income provides dividends and retained earnings, which upon investment in the firm promotes growth in stock prices. As net income is the numerator in the expression for earnings yield, an increase in net income could result in an increase in dividends or reinvestment of earnings in the firm, leading to higher returns on equity (net income/shareholders' equity investment). We propose that:

$\mathrm{H} 2$ : Earnings yield may be a significant predictor of return on equity.

\subsection{Earnings Yield and Stock Returns}

Earnings yield's effects on security returns may be based on its ability to predict future cash flows. [4] found that the ability to forecast the next period's cash flows and to capitalize on unfavorable news contained in cash flows in a timely fashion, predicted earnings. It follows that earnings are informative in providing expectations of future cash flows that contain such news. [8] extended this result to time periods up to five years, finding that earnings yield significantly predicted future cash flows in both the 1-year and 5-year time periods for US data for a time period from 1935-2001 and a pooled four-country sample using data from the United States, United Kingdom, France and Germany.

H3: Earnings yield may be a significant explanatory variable of stock returns.

\subsection{Earnings Yield and Economic Value Added}

Small firms in biotechnology and software maintain competitive advantage by producing a stream of products. Capital constraints may result in the need to use capital productively, i.e. by investing in products that have returns higher than their cost of capital or positive economic value added (EVA) products. Economic value added has its roots in [9] who defined the need for ongoing wealth creation as the excess of gross earnings over interest on capital. The creation of excess earnings is the function of earnings yield. The desire to increase EVA results in the rejection of projects with uncertain profitability, and the reduction of agency conflict in the quest for exceptional investment opportunities that contribute to higher market value added [10] [11]. By linking earnings yield to eco- 
nomic value added, this study shows that earnings yield can be a proxy for the ability to use capital judiciously.

H4: Earnings yield may be a significant predictor of economic value added.

\subsection{Earnings Yield and the Equity Multiplier}

Large firms have access to capital markets for debt and equity capital. These capital needs may be for acquisition in biotechnology and software and maintaining stores and inventory in a retrenching industry such as retail. The equity multiplier, which is defined as ( $1+$ Debt/Equity) is the ability of firms to raise capital-a measure upon which large, established firms may excel given that their ownership of assets and goodwill provide them with the collateral upon which they may increase their borrowing capacity. Firms with increasing earnings yield or growing net income in relation to stock prices may grow in size thereby enhancing their collateral base, and in turn their ability to borrow against this collateral. In other words, increased earnings yield may in turn increase the equity multiplier. This study supplements [12] finding that earnings yield represented a measure of safety capital for the typical firm.

H5: Earnings yield may be a significant explanatory variable of the equity multiplier.

\section{Data and Methodology}

A total of 3013 observations of NASDAQ stocks obtained directly from the National. Association of Security Dealers Automated Quotations were collected in 12 sectors and 101 industries, from 2010-2014. The NASDAQ Association makes the list of stocks available to the public through its website. The classification by sector consisted of: 1) basic industries $(2.7 \%) ; 2)$ transportation $(17 \%) ; 3)$ consumer non-durables (3\%); 4) finance $(24.9 \%)$; 5) consumer services $(11.3 \%)$; 6) technology $(9.7 \%)$; 7) consumer durables $(1.5 \%)$; 8) health care $(30.7 \%)$; 9) capital goods (7\%); 10) miscellaneous (3.3\%); 11) energy (2\%) and 12) public utilities (2\%). Income statement and balance sheet variables were extracted from Standard and Poor's COMPUSTAT Database. COMPUSTAT North America provides income statement and balance sheet data for publicly-traded firms in the United States, including net income, stockholders' equity, total assets, book value per share, taxes, total liabilities, net working capital, number of shares outstanding, earnings before interest and taxes, earnings per share, interest expense, revenue and cash balance. Annual stock returns, highest price per year, lowest price per year and closing price at the end of the year were obtained from the CRSP (Center for Research in Security Prices from the University of Chicago) database. CRSP provides security prices and security returns for U.S. stocks. Outcome variables of return on assets (ROA), return on equity (ROE), economic value added (EVA) and equity multiplier were computed from these financial statement variables.

Size was classified into levels $1-5$, by asset size. Asset sizes $<\$ 200$ million were coded 1, \$201 million - \$400 million were coded 2, \$401 million - \$1 billion 
were coded 3, $\$ 1.01$ billion - $\$ 5$ billion were 4 and $>\$ 5$ billion was 5 . In a smalllarge dichotomy, 1 and 2 were considered to be "small" and 4 and 5 were designated as "large". Volatility was measured by the standard deviation of high and low prices per year. Market risk was measured by stock beta coefficients with beta values $>1$ deemed "high risk" and beta values $<1$ deemed "low risk". Firmspecific risk was measured as (1-R2) in the regression of stock returns on valueweighted market returns. Firm-specific risk values of 0.1 and 0.02 were scored at Level 1, values of 0.3 and 0.4 formed at Level 2, values of 0.5 and 0.6 were at Level 3, 0.7 and 0.8 were at Level 4 and $>0.8$ was at Level 5. Low firm-specific risk consisted of Levels 1 and 2, while high firm-specific risk consisted of Levels 4 and 5.

Five separate multiple regressions of each outcome variable on earnings yield and two measures of value, i.e., book value per share and market-to-book were performed in accordance with the expressions listed below for the full sample and each of the industry subsamples. The Regression Analysis and Time Series (RATS) software was employed to conduct regressions. A correction for firstorder autocorrelation to maintain a Durbin-Watsonstatistic $=2$ was applied. Heteroscedasticity occurs when the error terms in a regression fail to vary systematically. The White-Hansen method [13] corrects for heteroscedasticity by creating a covariance matrix with consistent estimates of the standard errors of residuals.

$$
\begin{aligned}
R A_{t} & =\alpha+\beta 1 E Y_{t}+\beta 2 B V_{t}+\beta 3 M B t . \\
R O E_{t} & =\alpha 1 t+\beta 4 E Y_{t}+\beta 5 B V_{t}+\beta 6 M B t . \\
R E T_{t} & =\alpha 2 t+\beta 7 E Y_{t}+\beta 8 B V_{t}+\beta 9 M B_{t} . \\
E V A_{t} & =\alpha 3 t+\beta 10 E Y_{t}+\beta 11 B V_{t}+\beta 12 M B_{t} . \\
E M U L T_{t} & =\alpha 4 t+\beta 13 E Y_{t}+\beta 14 B V_{t}+\beta 15 M B t .
\end{aligned}
$$

$R A_{t}=$ Return on Assets at time $t$,

$E Y_{t}=$ Earnings Yield at time $t$,

$B V_{t}=$ Book Value at time $t$,

$M B_{t}=$ Market Value to Book Value at time $t$,

$R O E_{t}=$ Return on Equity at time $t$,

$R E T_{t}=$ Stock Returns at time $t$,

$E V A_{t}=$ Economic Value Added at time $t$,

$E M U L T_{t}=$ Equity Multiplier at time $t$.

\section{Results}

\subsection{Results (Full Sample)}

Table 1 shows that Hypotheses 1 - 4 were fully supported with earnings yield significantly influencing return on assets, return on equity, stock returns and economic value added. Hypothesis 5 was partly supported as earnings yield explained the equity multiplier within certain size and firm-specific risk categories. The various size and risk categories occur at Levels 1 - 5, with 1 being the smallest size and the lowest firm-specific risk.

Nonlinear relationships of earnings yield and return on assets at size Level 1 
Table 1. Results of OLS regressions for the full sample.

\begin{tabular}{cccccc}
\hline $\begin{array}{c}\text { Independent } \\
\text { Variables }\end{array}$ & $\begin{array}{c}\text { Return on } \\
\text { Assets }\end{array}$ & $\begin{array}{c}\text { Return on } \\
\text { Equity }\end{array}$ & $\begin{array}{c}\text { Stock } \\
\text { Return }\end{array}$ & $\begin{array}{c}\text { Economic } \\
\text { Value Added }\end{array}$ & $\begin{array}{c}\text { Equity } \\
\text { Multiplier }\end{array}$ \\
\hline $\begin{array}{c}\text { Constant } \\
\text { Earnings Yield }\end{array}$ & $\begin{array}{c}3.91^{* *} \\
1 \times 10^{-6^{* * *}}\end{array}$ & $\begin{array}{c}2.32^{* * *} \\
0.57^{* *}\end{array}$ & $\begin{array}{c}3.78^{* * *} \\
1 \times 10^{-6^{*}}\end{array}$ & $\begin{array}{c}9.13 \\
9.74^{* *}\end{array}$ & $\begin{array}{c}-4.3 \times 10^{-7} \\
\text { Book Value }\end{array}$ \\
$4.5 \times 10^{-5}$ & $2.4 \times 10^{-5}$ & $8.5 \times 10^{-5}$ & $-1 \times 10^{-2}$ & $5.3 \times 10^{-5}$ \\
$\begin{array}{c}\text { Market Value } \\
\text { to Book Value }\end{array}$ & 0.0 & 0.0 & 0.0 & $2.0 \times 10^{-6}$ & $0.9 \times 10^{-9}$ \\
Size & $-0.2^{* * *}$ & 0.0 & 0.0 & $4 \times 10^{-6^{* * *}}$ & 0.29 \\
Volatility & $1.7 \times 10^{-2^{*}}$ & $-3 \times 10^{-5}$ & $0.1^{* * *}$ & $-7.3^{* * *}$ & -0.5 \\
\hline
\end{tabular}

Note: $\mathrm{N}=3689,2547,3701,2546$ and 3689 respectively. $\mathrm{R} 2=0.1,1 \times 10^{-2}, 0.4,0.6$ and $1 \times 10^{-3} .{ }^{*} \mathrm{p}<0.05$, ${ }^{* *} \mathrm{p}<0.01,{ }^{* *} \mathrm{p}<0.001$. Dependent Variables include return on assets, return on equity, stock returns, economic value added and the equity multiplier.

were observed in all firm-specific risk categories. Linear relationships of earnings yield and return on assets were found at both size Level 2 at all firm-specific risk levels with the exception of Level 2. Essentially, earnings yield was related to return on assets for small firms at low risk levels. Nonlinear relationships of logarithmic and quadratic forms were observed for the smallest firms with linearity predominating at higher (Level 4) firm-specific risk levels. For stock returns as the criterion variable, no specific pattern emerged with both linear and nonlinear relationships being found for small firms at low risk levels. Earnings yield significantly explained the variation in economic value added in predominantly large firms with both low and high firm-specific risk levels. At small sizes only earnings yield-economic value added relationships at the highest risk levels were significant. Earnings yield significantly influenced the variation in equity multiplier at all risk levels following a linear functional form.

\subsection{Results (Industry)}

\subsubsection{Oil and Gas Industry}

Table 2 shows the impact of earnings yield on the criteria in the oil and gas industry. In Panel A, which depicts results for small firms, low market risk firms (low MR), may be those which engage in traditional oilfield and offshore drilling, while high market risk firms (high MR), may be those which are pursuing new drilling techniques such as the fracking of shale rock. Low firm-specific risk firms (Low FR) may drill in existing locations, while high firm-specific risk firms (high FR) may seek new locations. If oil extraction occurs in hitherto unexplored shale rock locations, given that there is no prior knowledge of the task, only the minimal goal of achieving operational efficiency may be realistic as seen in the ability of earnings yield to influence return on assets (regression coefficient = $1.6, p<0.05)$ and return to shareholders through significant effect on return on equity (regression coefficient $=6.2, \mathrm{p}<0.05$ ) for high MR, high FR firms. If drilling occurs in traditional set tings (low MR), even if new locations are pursued (high FR), prior knowledge of the activity exists, so that more ambitious goals may be pursued. Earnings yield acts as a measure of operational efficiency 
Table 2. Industry analysis of the oil and gas industry.

Panel A: Firm characteristics of small size, Market Risk (MR) and Firm-Specific Risk (FR).

\begin{tabular}{|c|c|c|c|c|c|c|c|}
\hline $\begin{array}{l}\text { Independent } \\
\text { Variables }\end{array}$ & $\begin{array}{c}\text { Return on } \\
\text { Assets } \\
\text { High MR High } \\
\text { FR }\end{array}$ & $\begin{array}{c}\text { Return on } \\
\text { Equity } \\
\text { High MR High } \\
\text { FR }\end{array}$ & $\begin{array}{l}\text { Return on } \\
\text { Assets } \\
\text { Low MR } \\
\text { High FR }\end{array}$ & $\begin{array}{l}\text { Return on } \\
\text { Equity } \\
\text { Low MR } \\
\text { High FR }\end{array}$ & $\begin{array}{c}\text { Stock Return } \\
\text { Low MR } \\
\text { High FR }\end{array}$ & $\begin{array}{c}\text { Economic } \\
\text { Value Added } \\
\text { Low MR } \\
\text { High FR }\end{array}$ & $\begin{array}{c}\text { Equity } \\
\text { Multiplier } \\
\text { Low MR } \\
\text { High FR }\end{array}$ \\
\hline Constant & 0.59 & -0.28 & 0.62 & -0.53 & -0.24 & $1.71^{* * *}$ & $6.50^{* * *}$ \\
\hline Earnings Yield & $1.6^{*}$ & $6.2^{*}$ & $8.8 \times 10^{-7}$ & $1.0 \times 10^{-6^{* *}}$ & $5.1 \times 10^{-3^{* * *}}$ & $4.5 \times 10^{-5^{*}}$ & $0.09^{* *}$ \\
\hline Book Value & $7.7 \times 10^{-4}$ & 0.1 & $-0.02^{*}$ & $-0.02^{* *}$ & $-0.03^{* * *}$ & $-1.8^{* *}$ & $-0.18^{* * *}$ \\
\hline $\begin{array}{c}\text { Market to } \\
\text { Book }\end{array}$ & $3 \times 10^{-9}$ & $6 \times 10^{-9}$ & $1.0^{* * *}$ & $1.0^{* * *}$ & $1.0^{* * *}$ & $17.7^{* * *}$ & $-0.47^{* * *}$ \\
\hline
\end{tabular}

Panel B: Firm characteristics of large size, Market Risk (MR) and Firm-Specific Risk (FR).

\begin{tabular}{cccccccc}
\hline $\begin{array}{c}\text { Independent } \\
\text { Variables }\end{array}$ & $\begin{array}{c}\text { Return on } \\
\text { Assets High } \\
\text { MR Low FR }\end{array}$ & $\begin{array}{c}\text { Return on } \\
\text { Equity High } \\
\text { MR Low FR }\end{array}$ & $\begin{array}{c}\text { Stock Returns } \\
\text { High MR Low } \\
\text { FR }\end{array}$ & $\begin{array}{c}\text { Equity } \\
\text { Multiplier } \\
\text { High MR Low } \\
\text { FR }\end{array}$ & $\begin{array}{c}\text { Return on } \\
\text { Assets High } \\
\text { MR High FR }\end{array}$ & $\begin{array}{c}\text { Return on } \\
\text { Equity High } \\
\text { MR High FR }\end{array}$ & $\begin{array}{c}\text { Economic } \\
\text { Value Added } \\
\text { High MR } \\
\text { High FR }\end{array}$ \\
\hline Constant & 0.14 & 0.13 & -2.82 & $3.39^{* *}$ & 0.18 & 0.14 & 7 \\
Earnings Yield & 0.20 & $0.38^{* *}$ & $2.2 \times 10^{-2^{*}}$ & $3.12^{*}$ & $0.19^{*}$ & $0.3^{*}$ & -0.01 \\
Book Value & $-7.9 \times 10^{-3}$ & $-7.6 \times 10^{-3}$ & $2.0 \times 10^{-1^{* *}}$ & $-0.04^{* *}$ & -0.01 & 0.01 \\
Market to Book & $3.3 \times 10^{-3}$ & $1.6 \times 10^{-2}$ & -0.12 & -0.06 & 0.01 & 0.03 & 1 \\
\hline
\end{tabular}

Note: $\mathrm{N}$ ranges from 20 - 27. R2 ranges from $0.2-0.99$. Dependent variables include return on assets, return on equity, stock returns, economic value added and the equity multiplier. ${ }^{*} \mathrm{p}<0.05,{ }^{* *} \mathrm{p}<0.01,{ }^{* * *} \mathrm{p}<0.001$.

(regression coefficient of $8.8 \times 10^{-7}$ with return on assets), return to shareholders (regression coefficient of $1 \times 10^{-6}, \mathrm{p}<0.01$, with return on equity and regression coefficient of $5.1 \times 10^{-6}, \mathrm{p}<0.01$ with stock returns), addition to firm value (regression coefficient of $4.5 \times 10^{-5}, \mathrm{p}<0.05$ with economic value added) and the ability to acquire additional debt (regression coefficient of $0.09, \mathrm{p}<0.01$ with equity multiplier).

Panel B of Table 2 shows results for large oil and gas firms with high market risk. Such firms may be large shale rock drillers, who may elect to diversify synergistically by investing in the production of oil and gas by-products, thereby, reducing firm-specific risk. At a minimum, acquirers must demonstrate operational efficiency and the ability to earn returns for shareholders as seen in regression coefficients of $0.2, \mathrm{p}<0.05$ for earnings yield and return on assets and $0.38, \mathrm{p}<0.001,0.02, \mathrm{p}<0.05$ for earnings yield and return on equity. As diversification is capital-intensive, the ability of acquirers to increase debt capacity as measured by the influence of earnings yield on the equity multiplier assumes importance (significant regression coefficient $=3.1, \mathrm{p}<0.001$ ). Yet, other shale rock drillers may not diversify relying solely on the revenue from shale rock drilling leading to high firm-specific risk. Such firms are expected to be capital-constrained. Hence, earnings yield predicts the ability to add firm value for capital-constrained firms (regression coefficient $=2.3, \mathrm{p}<0.01$ with economic value added). Further, earnings yield predicts operational efficiency (regression coefficient $=0.19, \mathrm{p}<0.05$ with return on assets) and return to shareholders (re- 
gression coefficient $=0.31, \mathrm{p}<0.05$ with return on equity)

\subsubsection{The Biotechnology Industry}

The impact of earnings yield on outcomes in the biotechnology industry is shown in Table 3 with Panel A examining small firms and Panel B describing large firms. Biotechnology firms produce new medicines for the treatment of conditions with certain market potential, such as diabetes (low market risk firms) and uncertain market potential, such as drugs to treat rare liver diseases

Table 3. Industry analysis of the biotechnology industry.

Panel A: Firm characteristics of small size, Market Risk (MR) and Firm-Specific Risk (FR).

\begin{tabular}{|c|c|c|c|c|c|c|c|}
\hline $\begin{array}{l}\text { Independent } \\
\text { Variables }\end{array}$ & $\begin{array}{l}\text { Return on } \\
\text { Assets Low } \\
\text { MR Low FR }\end{array}$ & $\begin{array}{l}\text { Return on } \\
\text { Equity Low } \\
\text { MR Low FR }\end{array}$ & $\begin{array}{l}\text { Return on } \\
\text { Assets High } \\
\text { MR Low FR }\end{array}$ & $\begin{array}{l}\text { Return on } \\
\text { Equity High } \\
\text { MR Low FR }\end{array}$ & $\begin{array}{c}\text { Economic Value } \\
\text { Added High MR } \\
\text { Low FR }\end{array}$ & $\begin{array}{c}\text { Return on } \\
\text { Assets High } \\
\text { MR High FR }\end{array}$ & $\begin{array}{c}\text { Return on } \\
\text { Equity High } \\
\text { MR High FR }\end{array}$ \\
\hline Constant & $-1.2^{* * *}$ & $5.0^{* * *}$ & 0.03 & 1.29 & -4.4 & -0.25 & 0.49 \\
\hline Earnings Yield & $3.9 \times 10^{-5^{* * *}}$ & $1.2 \times 10^{-4^{*}}$ & $3.3 \times 10^{-5^{*}}$ & $2.5 \times 10^{-5^{*}}$ & $6.7^{*}$ & $7.3 \times 10^{-6^{* * *}}$ & $5 \times 10^{-6^{* * *}}$ \\
\hline Book Value & $0.6^{* * *}$ & $1.2^{* * *}$ & 0.02 & 0.06 & $6.5 \times 10^{-3}$ & $2.2 \times 10^{-2^{* * *}}$ & $2.4 \times 10^{-3}$ \\
\hline $\begin{array}{c}\text { Market to } \\
\text { Book }\end{array}$ & 0.00 & 0.00 & $7.1 \times 10^{-7 * * *}$ & $5.7 \times 10^{-7^{*}}$ & $4.2 \times 10^{-6}$ & $1.6 \times 10^{-8}$ & $1.3 \times 10^{-6^{* * *}}$ \\
\hline
\end{tabular}

Panel A Continued: Firm characteristics of small size, Market Risk (MR) and Firm-Specific Risk (FR).

\begin{tabular}{cccccc}
\hline $\begin{array}{c}\text { Independent } \\
\text { Variables }\end{array}$ & $\begin{array}{c}\text { Stock Returns } \\
\text { High MR High FR }\end{array}$ & $\begin{array}{c}\text { Economic Value } \\
\text { Added High MR } \\
\text { High FR }\end{array}$ & $\begin{array}{c}\text { Equity Multiplier } \\
\text { High MR High FR }\end{array}$ & $\begin{array}{c}\text { Return on Assets } \\
\text { Low MR High FR }\end{array}$ & $\begin{array}{c}\text { Return on Equity } \\
\text { Low MR High FR }\end{array}$ \\
\hline Constant & $5.5^{* * *}$ & -1.5 & $1.9^{* * *}$ & -0.16 & -0.02 \\
Earnings Yield & $8 \times 10^{-6^{* * *}}$ & $8.8 \times 10^{-5^{* * *}}$ & $1.3 \times 10^{-5^{* * *}}$ & $2.9^{* * *}$ & $2.7^{* * *}$ \\
Book Value & $2.6 \times 10^{-3^{* * *}}$ & $0.1^{* *}$ & $1.1 \times 10^{-2}$ & $1.6 \times 10^{-2}$ & $1.7 \times 10^{-2}$ \\
Market to Book & 0.00 & $3 \times 10^{-8}$ & $8.4 \times 10^{-7^{* * *}}$ & $1.1 \times 10^{-6}$ & 7.5 \\
\hline
\end{tabular}

Note: $\mathrm{N}$ ranges from 37 - 306. R2 ranges from 0.01 - 0.92. Dependent variables include return on assets, return on equity, stock returns, economic value added and the equity multiplier. ${ }^{*} \mathrm{p}<0.05,{ }^{* *} \mathrm{p}<0.01,{ }^{* * *} \mathrm{p}<0.001$.

Panel B: Firm characteristics of large size, Market Risk (MR) and Firm-Specific Risk (FR).

\begin{tabular}{cccccccc}
\hline \multirow{2}{*}{$\begin{array}{c}\text { Independent } \\
\text { Variables }\end{array}$} & $\begin{array}{c}\text { Return on Assets Return on Equity } \\
\text { High MR Low } \\
\text { FR }\end{array}$ & $\begin{array}{c}\text { Stock Return } \\
\text { HR Low }\end{array}$ & $\begin{array}{c}\text { Fronomic Value } \\
\text { High MR Low }\end{array}$ & $\begin{array}{c}\text { Return on } \\
\text { Added High MR } \\
\text { Fow FR }\end{array}$ & $\begin{array}{c}\text { Return on Assets } \\
\text { Assets Low MR } \\
\text { Low FR }\end{array}$ & $\begin{array}{c}\text { Return on } \\
\text { LR High }\end{array}$ & $\begin{array}{c}\text { Equity Low MR } \\
\text { High FR }\end{array}$ \\
\hline Constant & 0.02 & 0.06 & 0.01 & $-7.5^{*}$ & 0.11 & -0.02 & 0.36 \\
Earnings Yield & $0.4^{* * *}$ & $1.2^{* *}$ & $0.4^{*}$ & $1.1^{*}$ & $4.7^{*}$ & $0.3^{* * *}$ & $0.1^{* * *}$ \\
Book Value & $-2.9 \times 10^{-3}$ & 0.01 & $6.9 \times 10^{-3}$ & -1.5 & $2.5 \times 10^{-3}$ & $5.4 \times 10^{-4}$ & $2.1 \times 10^{-3}$ \\
Market to Book & $-1.8 \times 10^{-3}$ & 0.02 & $9.7 \times 10^{-3}$ & -5.0 & 0.00 & $7.4 \times 10^{-3^{* * *}}$ & $5.6 \times 10^{-2 * * *}$ \\
\hline
\end{tabular}

Panel B Continued: Firm characteristics of large size, Market Risk (MR) and Firm-Specific Risk (FR).

\begin{tabular}{cccccc}
\hline $\begin{array}{c}\text { Independent } \\
\text { Variables }\end{array}$ & $\begin{array}{c}\text { Stock Returns } \\
\text { Low MR High FR }\end{array}$ & $\begin{array}{c}\text { Equity Multiplier } \\
\text { Low MR High FR }\end{array}$ & $\begin{array}{c}\text { Return on Equity } \\
\text { High MR High FR }\end{array}$ & $\begin{array}{c}\text { Stock Returns } \\
\text { High MR High FR }\end{array}$ & $\begin{array}{c}\text { Economic Value Added } \\
\text { High MR High FR }\end{array}$ \\
\hline Constant & 0.02 & -0.3 & 0.01 & 0.03 & -2.0 \\
Earnings Yield & $7.5 \times 10^{-4^{*}}$ & $2.5^{* *}$ & $0.1^{*}$ & $0.05^{*}$ & $1.5^{* *}$ \\
Book Value & $-5.3 \times 10^{3}$ & -0.10 & $7.3 \times 10^{-3}$ & $-2.4 \times 10^{-3}$ & $1.8^{* *}$ \\
Market to Book & $1.0 \times 10^{-2}$ & $-1.7 \times 10^{-2}$ & $1.9 \times 10^{-8}$ & $-1.3 \times 10^{-8^{*}}$ & $7.2 \times 10^{-3^{* *}}$ \\
\hline
\end{tabular}

Note: $\mathrm{N}$ ranges from 9 - 31. R2 ranges from $0.16-0.96$. Dependent variables include return on assets, return on equity, stock returns, economic value added and the equity multiplier. ${ }^{*} \mathrm{p}<0.05,{ }^{* *} \mathrm{p}<0.01,{ }^{* * *} \mathrm{p}<0.001$. 
(high market risk firms). The industry may employ existing technology (low firm-specific risk) or new novel technology (high firm-specific risk) in drug development. Small firms must demonstrate operational efficiency and provide adequate return to shareholders for the production of drugs with definite market potential, i.e. low market risk (earnings yield has significant regression coefficients for return on assets, return on equity and shareholder return for low MR, low or high FR firms). For drugs with uncertain market acceptance, if existing technology is pursued in research and development, return to shareholders and value creation must be achieved within capital constraints.

Large biotechnology firms pursue synergistic acquisition with target firms in the same industry, such as the purchase of a small biotechnology firm producing medicines by a large biotechnology firm with similar product lines (low market risk). If existing technology continues to be employed by the target, firm-specific risk diminishes, or operational efficiency becomes the sole goal to be pursued for low MR, low FR firms. If new technology is being developed by the target, firm-specific risk grows, or it is incumbent upon the acquirer to demonstrate the ability to achieve returns for shareholders and raise additional capital to alleviate the increase in firm-specific risk. Non synergistic acquisitions occur with target firms in another industry, such as a pharmaceutical firm acquiring a maker of medical devices (high market risk). Regardless of firm-specific risk, these acquirers have the burden of proving that their capital is being employed productively or earnings yield significantly influences economic value added.

\subsubsection{The Computer Software Industry}

To maintain brevity, tables have not been included for the Computer Software Industry. Earnings yield was found to be significant in explaining all of the criteria of return on assets, return on equity, stock returns and the equity multiplier for both low and high market risk and low and high firm-specific risk firms of large and small size. For three of four types of small firms, capital constraints are binding. Therefore, these firms must demonstrate operational efficiency, the ability to meet shareholder returns and pursue projects whose return exceeds the cost of capital. The first type of firm is a low market risk, low firm-specific risk firm such as a social media firm that pursues social media applications. Risk levels are low in that the firm is merely creating new products at the same level of knowledge. Operational efficiency (regression coefficient of 1.1, $\mathrm{p}<0.001$ for earnings yield and return on assets), return to shareholders (regression coefficient of 1.1, p $<0.001$ and 2.9, $\mathrm{p}<0.001$ for earnings yield and stock returns), suggest that the project is productive in its ability to add value (regression coefficient of $0.4, \mathrm{p}<0.01$ with economic value added) for L MR, L FR firms. The second type of firm is a high market risk, low firm-specific risk firm. A virtual reality firm seeking to expand its repertoire by issuing a new game would be an example of this case. There is little firm-specific risk given that the game shares the technology of existing games. However, the novelty of virtual reality gaming ensures a high level of market risk, suggesting that capital constraints prevail. Accordingly, the virtual reality firm must demonstrate its ability to add value in 
addition to achieving operational efficiency and adequate shareholder returns with significant regression coefficients between earnings yield, return on assets and economic value added for H MR L FR firms. The third type of firm is a small computer firm may be that of a low market risk, high firm-specific risk firm. A social media firm undertaking a virtual reality project would fall into this category. Virtual reality is the playing of online games viewed through a threedimensional space. Since the firm's main product line is social media which is commonplace, the firm's main line of business does not arouse uncertainty; yet emerging virtual reality technology is highly uncertain in its potential for success and its ability to meet capital restrictions. Operational efficiency (regression coefficient $=0.5, \mathrm{p}<0.001$ for earnings yield and return on assets) and return to shareholders (regression coefficient of $0.5, \mathrm{p}<0.01$ for earnings yield and return on equity and regression coefficient of 3.2, $\mathrm{p}<0.01$ for earnings yield and stock returns) and economic value added objectives (regression coefficient of 4.7, p < 0.05 , for earnings yield and economic value added) were met.

The fourth type of small firm with high market risk and high firm-specific risk may exceed capital limits. One such example could be a virtual reality firm (with high market risk) which pursues a non-gaming application (high firm-specific risk). This firm may exceed capital limits, finding that the new technology requires more capital than is typically available to a small firm. This can be seen in a significant relationship between earnings yield and the equity multiplier of 1.9, $\mathrm{p}<0.05$ for H MR, H FR firms, or that the ability to raise additional capital through debt or equity depends upon continued profitability of the project. A positive association between earnings yield and economic value added (regression coefficient $=0.3, \mathrm{p}<0.05$ for $\mathrm{H} \mathrm{MR}, \mathrm{H}$ FR firms) indicates that the new application adds value to the firm, so that the firm is profitable, but needs additional capital, rendering the firm a potential takeover target. Large software firms may be considered to be acquirers. The first type of acquisition is that of a low market risk firm with low firm-specific risk purchasing at large firm. Consider a large social media firm acquiring a small social media firm. With the high level of product synergy, the firm expects to meet operational efficiency and shareholder return targets along with possibly increasing debt or equity investment to sustain the acquisition (significant regression coefficients of earnings yield with return on assets, return on equity and shareholder returns and equity multiplier of $2.0 \times 10^{-7}, \mathrm{p}<0.01,2.5 \times 10^{-6}, \mathrm{p}<0.001,7.6 \times 10^{-6}, \mathrm{p}<0.001$ and $\left.8.1 \times 10^{-5}, \mathrm{p}<0.001\right)$. The combined firm must prove the benefit of this acquisition by demonstrating the creation of value beyond the cost of capital (significant regression coefficient of earnings yield with economic value added of $2.1 \times$ $\left.10^{-2}, \mathrm{p}<0.001\right)$. The second type of acquisition is that of an acquirer with high market risk and low firm-specific risk, such as a robotics firm purchasing a similar robotics firm.

The only difference with the first type of acquisition is the lack of emphasis on economic value added as the considerable unpredictability of completely novel technology such as robotics renders it unrealistic to assume that capital constraints will be binding, hence, economic value added targets cannot be met. There- 
fore earnings yield was found to vary significantly with all criteria with the exception of economic value added.

\subsubsection{The Retail Industry}

The retail industry consists of small retail stores, with apparel, groceries and drug stores to name a few, through traditional brick-and-mortar and online venues. The industry is in retrenchment with this study's regression of the full sample of retailers revealing that declining revenues significantly explained earnings yield (regression coefficient $=-2.1, \mathrm{p}<0.001$ ). In low market risk, low firm-specific risk small retailers, such as small clothing stores selling traditional styles, retrenchment takes the form of meeting operational efficiency and shareholder return targets (see Table 4, Panel A, Columns 2 - 4, for significant associations of earnings yield with return on assets, return on equity and stock returns). For low market risk, high firm-specific risk small retailers, such as fast fashion, modern, creative styles at cut-rate prices attract youthful customers. Investments in inventory act as collateral for the acquisition of additional debt capital as shown by the significant association of earnings yield with the equity multiplier (Table 4, Panel A, Column 7). In high market risk, low firm-specific risk small retailers, such as the brick-and-mortar operations of small hardware stores, capital constraints abound with limited opportunities for expansion in the face of growing competitive threats from inexpensive large retailers and online sales, so that the ability to add value beyond the cost of capital is essential (as shown by the significant association of earnings yield with economic value added,

Table 4. Industry analysis of the retail industry.

Panel A: Firm characteristics of small size, Market Risk (MR) and Firm-Specific Risk (FR).

\begin{tabular}{cccccccc}
\hline $\begin{array}{c}\text { Independent } \\
\text { Variables }\end{array}$ & $\begin{array}{c}\text { Return on } \\
\text { Assets Low } \\
\text { MR High MR }\end{array}$ & $\begin{array}{c}\text { Return on } \\
\text { Equity Low } \\
\text { MR Low FR }\end{array}$ & $\begin{array}{c}\text { Stock Returns } \\
\text { Low MR Low } \\
\text { FR }\end{array}$ & $\begin{array}{c}\text { Return on } \\
\text { Assets Low } \\
\text { MR High FR }\end{array}$ & $\begin{array}{c}\text { Return on } \\
\text { Equity Low } \\
\text { MR High FR }\end{array}$ & $\begin{array}{c}\text { Stock } \\
\text { Returns Low } \\
\text { MR High FR }\end{array}$ & $\begin{array}{c}\text { Equity } \\
\text { Multiplier Low } \\
\text { MR High FR }\end{array}$ \\
\hline Constant & -0.05 & 0.06 & 0.71 & -0.1 & 0.06 & $4.4^{* * *}$ & $1.5^{* * *}$ \\
Earnings Yield & $7.1 \times 10^{-2^{* * *}}$ & $0.25^{* * *}$ & $0.39^{* * *}$ & $7.6 \times 10^{-5^{* * *}}$ & $7.5 \times 10^{-5^{* * *}}$ & $5.1 \times 10^{-5^{* * *}}$ & $6.5 \times 10^{-6^{* * *}}$ \\
Book Value & $1.6 \times 10^{-2}$ & $7.1 \times 10^{-3}$ & $7.7 \times 10^{-2^{*}}$ & $7.3 \times 10^{-2^{* *}}$ & $5.6 \times 10^{-2}$ & $5.1 \times 10^{-2}$ & $2.2 \times 10^{-2}$ \\
$\begin{array}{c}\text { Market to } \\
\text { Book }\end{array}$ & $-2.5 \times 10^{-8}$ & $-1.8 \times 10^{-7}$ & $-1.8 \times 10^{-6^{* *}}$ & $6.4 \times 10^{-8}$ & $-5 \times 10^{-9}$ & $1.1 \times 10^{-6}$ & $4.3 \times 10^{-8}$ \\
\hline
\end{tabular}

Panel A Continued: Firm characteristics of small size, Market Risk (MR) and Firm-Specific Risk (FR).

\begin{tabular}{ccccccc}
\hline $\begin{array}{c}\text { Independent } \\
\text { Variables }\end{array}$ & $\begin{array}{c}\text { Return on Equity } \\
\text { High MR Low FR }\end{array}$ & $\begin{array}{c}\text { Economic Value } \\
\text { Added High MR } \\
\text { Low FR }\end{array}$ & $\begin{array}{c}\text { Equity Multiplier } \\
\text { High MR Low FR }\end{array}$ & $\begin{array}{c}\text { Return on Assets } \\
\text { High MR High FR }\end{array}$ & $\begin{array}{c}\text { Return on Equity } \\
\text { High MR High FR }\end{array}$ & $\begin{array}{c}\text { Stock Returns } \\
\text { High MR High FR }\end{array}$ \\
\hline Constant & $-0.1^{*}$ & $1.2^{* * *}$ & $1.7^{* * *}$ & 2.2 & 0.10 & $0.05^{* * *}$ \\
Earnings Yield & $0.9^{* * *}$ & $8.6^{* * *}$ & $-0.6^{* *}$ & $1.0 \times 10^{-4^{* *}}$ & $7.8 \times 10^{-5^{* *}}$ & $0.2^{* *}$ \\
Book Value & $1.8 \times 10^{-3^{* * *}}$ & -0.2 & $2.5 \times 10^{-4}$ & $8.3 \times 10^{-2}$ & $2.7 \times 10^{-2}$ & $-4.4 \times 10^{-2^{*}}$ \\
Market to Book & $0.1^{* * *}$ & -1.7 & $0.2^{* * *}$ & $1.6 \times 10^{-6}$ & $2.9 \times 10^{-6}$ & $1.3 \times 10^{-5^{* * *}}$ \\
\hline
\end{tabular}

Note: $\mathrm{N}$ ranges from $30-81$. R2 ranges from $0.21-0.94$. Dependent variables include return on assets, return on equity, stock returns, economic value added and the equity multiplier. ${ }^{*} \mathrm{p}<0.05,{ }^{* *} \mathrm{p}<0.01,{ }^{* * *} \mathrm{p}<0.001$. 
Table 4, Panel A Continued, Column 1).

Large retailers may include ground-based department stores whose low market risk and low firm-specific risk is supported by sales of existing merchandise to a shrinking customer base so that retrenchment assumes the form of meeting goals of operational efficiency and return on investment (see significant associations of earnings yield with return on assets of $1.3, \mathrm{p}<0.001$, and earnings yield with return on equity of $2.6, \mathrm{p}<0.05$ ) along with raising additional debt using inventory as collateral (see the significant association of earnings yield with the equity multiplier of 8.04, $\mathrm{p}<0.001$ ). Similar results were obtained for high market risk, low firm-specific risk large retailers such as the ground operations of specialty hardware stores, such as kitchen and bathroom remodelers.

\section{Conclusions and Recommendations for Future Research}

Earnings yield has been found to predict return on assets, return on equity, stock returns, economic value added and the equity multiplier. As the literature has indicated that it is the ability of earnings to predict future cash flows which are the underlying cause of the viability of earnings yield as a measure of financial performance, it is possible that as earnings yield transmits signals that as future cash flows are expected to be healthy, outcome variables will increase. The implication of strong future cash flows suggests that assets are being used productively to generate cash (return on assets), the investments made in the firm are profitable (return on equity), that stock prices increase from expectations of a continuous stream of future cash flows (stock returns), that firm value is increasing as projects with higher operating profits than the cost of capital are implemented (economic value added) and that the ability to acquire additional debt capital is increasing as cash flows increase creditworthiness (equity multiplier). Future research should empirically verify the explanatory capability of earnings yield of future cash flows. Relationships of earnings yield with size and volatility may be more complex than that sets forth in earlier studies. Size and volatility have historically been examined independently in their influence on earnings yield and stock returns. Size effects traditionally consisted of small, high earnings yield firms, exhibiting higher stock returns than large, low earnings yield firms [3] [7]. Likewise, volatility effects consisted of significant prediction of stock returns by firms with high firm-specific risk beyond that predicted by earnings yield [2] [14]. This study examined the joint effect of size and firm-specific risk on earnings yield and all outcomes. We extended [2]'s and [14]'s results for firm-specific risk by finding a joint effect of size and firm-specific risk for size Levels 1 - 5 and firm-specific risk Levels 1 - 5 with 1 being the smallest. Significant relationships for size-firm-specific risk combinations were observed (size listed first in each pair) including earnings yield and return on assets $(1,1 ; 1,2 ; 1,4 ; 1,5 ; 2,1 ; 2,3 ; 2,4 ; 2,5 ; 3,2 ; 3,5 ; 4,2 ; 4,3 ; 4,4 ; 4$, 5 ), earnings yield and return on equity $(1,3 ; 1,4 ; 1,5 ; 2,1 ; 2,3 ; 2,4 ; 2,5 ; 4,3 ; 4$, $4 ; 2,2 ; 5,4)$, earnings yield and stock returns $(1,1 ; 1,4 ; 1,5 ; 2,1 ; 2,2 ; 4,1 ; 5,2 ; 5$, 4 ), earnings yield and economic value added $(5,1 ; 5,2 ; 5,4 ; 5,5 ; 4,2 ; 2,4 ; 1,2)$ 
and earnings yield and the equity multiplier $(1,2 ; 2,1 ; 2,2 ; 2,3 ; 3,3 ; 3,4 ; 3,5 ; 4$, $2 ; 4,3 ; 4,4 ; 5,1 ; 5,2 ; 5,4)$. At the industry level, earnings yield assumes different roles depending upon the outcome in the oil and gas industry. If drilling occurs in traditional settings, earnings yield acts as a measure of operational efficiency, return to shareholders, addition to firm value and the ability to acquire additional debt. Positive earnings have been reported by such firms even with deteriorating oil prices [15]. Earnings yield becomes a predictor of debt capacity for large shale rock drillers who engage in the acquisition of target firms. Yet, other shale rock drillers may elect to remain as single-firm operations resulting in capital-constraints with earnings yield predicting the ability to add firm value for capital-constrained firms.

Biotechnology firms produce new medicines for the treatment of conditions with certain market potential and uncertain market potential. In small firms, earnings yield acts as a measure of operational efficiency and return to shareholders for the production of drugs with definite market potential. For drugs with uncertain market acceptance, if existing technology is pursued in research and development, earnings yield measures the return to shareholders and value creation within capital constraints. If market potential is unknown and new technology is being used, earnings yield demonstrates the ability to acquire funds through debt. Large biotechnology is frequently engaged in acquisitions to add to their product lines left wanting from sudden patent expirations [16]. If new technology is being developed by the target, earnings yield measures the ability of the acquirer to achieve returns for shareholders and raise additional capital.

Acquirers of firms in other industries have the burden of proving that their capital is being employed productively or earnings yield significantly influences economic value added. Large software firms may be considered to be acquirers. The two extreme cases are the very stable acquirers with low market risk and low firm-specific risk and their counterparts with excessively high market risk and high firm-specific risk. With low risk, expectations are considerable so that all earnings yield is associated with return on assets, return on equity stock returns and economic value added. At high risk, only minimum goals of return on assets and return on equity need to be met, so that earnings yield is just associated with these targets. For the two intermediate levels of risk, i.e. high market risk, low firm-specific risk, earnings yield becomes a measure of debt capacity with significant associations with the equity multiplier. This suggests that additional capital is raised for acquisitions involving a moderate level of risk. The retail industry is in retrenchment. Small firms at low risk may employ earnings yield to measure operational efficiency and shareholder returns. As risk becomes moderate, additional capital is needed, which may be obtained using inventory as collateral. At this juncture, earnings yield becomes a predictor of the equity multiplier. Yet, large firms have much more extensive holdings of inventory, rendering them capable of raising considerable amounts of external capital. Therefore, for all large firms, regardless of risk, earnings yield acts as a measure of ad- 
ditional debt capacity in its association with the equity multiplier.

\section{References}

[1] Wu, C. and Wang, X.M. (2000) The Predictive Ability of Dividend and Earnings Yields for Long-Term Stock Returns. The Financial Review, 35, 97-124. https://doi.org/10.1111/j.1540-6288.2000.tb01416.x

[2] Basu, S. (1983) The Relationship between Earnings Yield, Market Value and Return for NYSE Common Stocks. Journal of Financial Economics, 12, 129-156. https://doi.org/10.1016/0304-405X(83)90031-4

[3] Rogers, R.C. (1988) The Relationship between Earnings Yield and Market Value: Evidence from the American Stock Exchange. The Financial Review, 23, 65-80. https://doi.org/10.1111/j.1540-6288.1988.tb00775.x

[4] Barton, J., Hansen, T.B. and Pownall, G. (2010) Which Performance Measures Do Investors around the World Value the Most-And Why? The Accounting Review, 85, 753-789. https://doi.org/10.2308/accr.2010.85.3.753

[5] Hjalmarsson, E. (2010) Predicting Global Stock Returns. Journal of Financial and Quantitative Analysis, 45, 49-80. https://doi.org/10.1017/S0022109009990469

[6] Jaffe, J., Keim, D.B. and Westerfield, R. (1989) Earnings Yields, Market Values, and Stock Returns. Journal of Finance, 44, 135-148. https://doi.org/10.1111/j.1540-6261.1989.tb02408.x

[7] Cheung, Y.L., Leung, Y.M. and Wong, K.F. (1994) Small Firm Effect: Evidence from the Korean Stock Exchange. Small Business Economics, 6, 373-379.

https://doi.org/10.1007/BF01065140

[8] Ang, A. and Bekaert, G. (2007) Stock Return Predictability: Is It There? Review of Financial Studies, 20, 651-707. https://doi.org/10.1093/rfs/hhl021

[9] Marshall, A. (1920) Principles of Economics. Macmillan, London.

[10] LiDestri, A.M., Picone, P.M. and Mina, A. (2012) Bringing Strategy Back into Financial Systems of Performance Measurement: Integrating EVA and PBC. Business Systems Review, 1, 85-102.

[11] Milunovich, S. and Tsuei, A. (1996) $\mathrm{EVA}^{\oplus}$ in the Computer Industry. Journal of Applied Corporate Finance, 9, 104-116. https://doi.org/10.1111/j.1745-6622.1996.tb00108.x

[12] Benishay, H. (1961) Variability in Earnings-Price Ratios of Corporate Equities. The American Economic Review, 51, 81-94.

[13] White, H. (1980) A Heteroskedasticity-Consistent Covariance Matrix Estimator and a Direct Test of Heteroskedasticity. Econometrica, 48, 817-838. https://doi.org/10.2307/1912934

[14] Frankel, R. and Lee, C.M. (1998) Accounting Valuation, Market Expectation, and Cross-Sectional Stock Returns. Journal of Accounting and Economics, 25, 283-319. https://doi.org/10.1016/S0165-4101(98)00026-3

[15] Jackson, L. (2016) US Oil Production Plunges: 3 Companies That Should Be Profitable This Year, 24/7 Wall St., 1. https://wallst.com/energy-business

[16] Danzon, P.M., Epstein, A. and Nicholson, S. (2003) Mergers and Acquisitions in the Pharmaceutical and Biotech Industries. Managerial and Decision Economics, 28, 307-328. https://doi.org/10.1002/mde.1343 
Submit or recommend next manuscript to SCIRP and we will provide best service for you:

Accepting pre-submission inquiries through Email, Facebook, LinkedIn, Twitter, etc. A wide selection of journals (inclusive of 9 subjects, more than 200 journals)

Providing 24-hour high-quality service

User-friendly online submission system

Fair and swift peer-review system

Efficient typesetting and proofreading procedure

Display of the result of downloads and visits, as well as the number of cited articles Maximum dissemination of your research work

Submit your manuscript at: http://papersubmission.scirp.org/

Or contact me@scirp.org 